\title{
Vliv výukového programu na rozvíjení environmentální senzitivity žáků
}

\author{
Jan Činčera
}

Envigogika 2012/VII/2- Recenzované články/ Reviewed Papers

Publikováno/Published 30. 09. 2012

DOI: http://dx.doi.org/10.14712/18023061.73

\begin{abstract}
Abstrakt:
Článek prezentuje evaluaci výukového programu „Les je př́tel člověka". Program vychází z metodiky "modelu učení plynutím" Josepha Cornella a usiluje a rozvíjení environmentální senzitivity dětí. Žáci dostali bezprostředně před programem a pak 1-3 týdny po programu stejný dotazník, do kterého vyplňovali zrakové, sluchové a hmatové vjemy, které si vybavovali ze svého posledního pobytu $v$ lese. Zaznamenané reflexe pak byly kódovány a kategorizovány. $V$ rámci analýzy pak bylo porovnáváno, zda se počty rưzných smyslových vjemů $v$ dotazníku po programu liší od počtů, uváděných před programem.
\end{abstract}

Evaluace ukázala, že k takovému nárůstu dochází u žáků na prvním stupni, program také více pưsobil na dívky. Efekt na chlapce a na starší žáky byl statisticky neprůkazný. Program tedy pravděpodobně zvyšuje vnímavost vưči prírodě, ale jen pro některé skupiny účastníků.

\section{Klíčová slova:}

Evaluace programu, Joseph Cornell, flow learning model, environmentální senzitivita

\section{Abstract:}

The article presents an evaluation research of the program "Forest is a friend of a man". The program applies a flow learning model invented by Joseph Cornell and aims on developing an environmental sensitivity of children. Pupils obtained the same questionnaire immediately before and then 1-3 weeks after the program and were asked to notice visual, oral and tactile perception they remember from their last visit of a forest. All the notices were coded and categorized. In the analyses, numbers of various sensual perceptions before and after the program were compared.

The evaluation revealed that the number of sensual perceptions after the program increased for the group of $1^{\text {st }}$ stage pupils; girls were more influenced than boys. The effect on boys and older pupils was not significant. The program probably increases environmental sensitivity but only for the mentioned groups of participants.

\section{Key words:}

Program evaluation, Joseph Cornell, flow learning model, environmental sensitivity 


\section{Úvod}

Jedním z cílů environmentální výchovy podle Tbiliské deklarace bylo pomoci jednotlivcům i skupinám rozvíjet jejich senzitivitu k životnímu prostředí a jeho problémům (Tbilisi Declaration, 1977). Podle interpretace Louise Chawlové (1998b) byla environmentální senzitivita $v$ té době chápána jako jedna $z$ charakteristik tzv. environmentálního vědomí (environmental awareness), tedy jedné z hlavních cílových oblastí environmentální výchovy. Jako taková byla zahrnuta i do navazujícího, široce respektovaného vymezení cílů environmentální výchovy od Hungerforda, Peytona a Wilkeho (1980).

V době Tbiliské konference nebyla dosud většina cílových oblastí environmentální výchovy operacionalizována a vzájemné vztahy mezi deklarovanými cílovými oblastmi nebyly dosud výzkumně uchopeny. Pro výzkum environmentální senzitivity se staly klíčovými práce Thomase Tannera (1998), který v roce 1980 založil tradici výzkumu tzv. významných životních zkušeností. Tanner vycházel z přesvědčení, že environmentálně aktivní jedinci, jako jsou aktivisté či environmentální vychovatelé, představují určité vzory odpovědného chování pro populaci. Pokud by se podařilo identifikovat, jaké významné životní zkušenosti je $v$ jejich životní dráze ovlivnily, získali bychom cenné informace pro to, na co bychom se měli zaměřit v environmentální výchově.

$\mathrm{Na}$ Tannera navázala Nancy Petersonová (2005), která provázala Tannerovu myšlenku výzkumu významných životních zkušeností s konceptem environmentální senzitivity postulovaným Tbiliskou deklarací. Životní zkušenosti podle jejího názoru rozvíjí určité afektivní atributy, jejichž důsledkem je individuální pohled na životní prostředí z empatické perspektivy a následně motivace k odpovědnému environmentálnímu chování. Tuto sadu afektivních atributů pak označila jako „environmentální senzitivitu”.

Na základě navazujících studií zkoumajících vztah mezi environmentální senzitivitou a odpovědným chováním (Sward a Marcinkowski, 2005) označili Hungerford a Volková (1990) environmentální senzitivitu, chápanou zde jako „empatická perspektiva k životnímu prostředí", za nejvýznamnější tzv. vstupní proměnnou ve svém modelu odpovědného environmentálního chování. Přestože ale environmentální senzitivita hraje podle jejich názoru důležitou roli, neměla by se podle nich zahrnovat do školního kurikula, protože je obtížné ji ve školních podmínkách rozvíjet. Doménou rozvíjení environmentální sensitivity tak měla být zejména neformální a informální výchova.

Je ale skutečně nemožné rozvíjet environmentální senzitivitu v rámci formálního vzdělávání? Podle Kima (2003) by kvưli svému významu neměla být ze školního prostředí vynechána. V České republice byla environmentální senzitivita zahrnuta jako jedna z klíčových oblastí do tzv. Doporučených očekávaných výstupů pro Rámcový vzdělávací program pro základní vzdělávání a pro gymnázia (Pastorová a kol., 2011).

Nabízí se proto otázka, jakým způsobem environmentální senzitivitu na školách rozvíjet. Podle řady realizovaných výzkumů souvisí environmentální senzitivita se vztahem k prírodě a klíčovým faktorem pro její rozvinutí jsou prímé a dlouhodobé prožitky v prírodě. Podle Sivekova (2002) výzkumu středoškolských studentů je klíčovým faktorem právě čas strávený $v$ přírodě. Pozitivní, opakovaný prožitek $v$ přírodě je na prvním místě i ve studiích významných životních zkušeností Louise Chawlové (1999), na dalších místech pak jsou vliv rodiny, neformální organizace, vztah ke konkrétnímu místu či zkušenost ztráty či poškození oblíbeného místa $v$ přírodě. Stejný vzorec se opakoval i ve srovnávacím výzkumu provedeném v devíti zemích v severní Americe, Evropě, Asii či Africe (Palmer a kol., 1998; Palmer a kol., 1999).

Furihata a kol. (2007) potvrzuje význam kontaktu s přírodou pro rozvíjení environmentální senzitivity i z Japonska. Podle něj je ale vhodné rozlišit dva druhy významných životních zkušeností. Základní životní zkušenosti jsou podle něj ty, které 
v dětství formují environmentální senzitivitu. $V$ průběhu dalšího života se pak objevuje druhý typ, přímé životní zkušenosti, které jedince př́mo vedou k environmentální akci.

Jednoznačně znějící poselství výzkumu významných životních zkušeností ale komplikují terminologické i metodologické spory.

Jak upozorňuje Chawlová (1998b), definice environmentální senzitivity jako empatické perspektivy k životnímu prostředí připouští určitou dvojznačnost výkladu. Podle prvního jde o schopnost identifikace s prírodou, tedy určitého vcítění se do př́rody. Podle druhého mưže jít o "animaci" prírody podle konceptů vlastního vnitřního světa, tedy určité "promítnutí se" do prírody. Podle jejího názoru pracují provedené výzkumy s prvním pojetím a opomíjí druhé. Určitá antropomorfizace prírody, její zabydlení pohádkovými bytostmi atd., přitom ale také mưže hrát pro formování environmentální senzitivity důležitou roli. Chawlová následně nabízí alternativní definici environmentální senzitivity jako zájmu a starosti o životní prostředí. $\mathrm{K}$ tomuto pojetí se $\mathrm{v}$ českém prostředí vztahuje např́íklad Jančaříková (2009).

S trochu užším pojetím environmentální senzitivity přichází u nás Krajhanzl (2010), který ji definuje jako vnímavost a všímavost vǔči přírodě. Člověka s vysokou environmentální senzitivitou podle něj příroda zajímá, "spatří a uslyší to, co mnozí míjejí, ucítí a pocítí to, o čem druzí nemívají ponětí... Je vnímavý ke kráse zdravé prírody i k jejím zraněním a bolestem." (s. 28). Přestože takové pojetí je oproti výše uvedeným konceptům poněkud redukované, Ize $s$ autorem souhlasit, že vnímavost vưči prŕírodě představuje důležitou složku environmentální senzitivity a právě schopnost jedince zaznamenat a reflektovat okolní prírodu může být důležitým indikátorem kvality programu environmentální výchovy, který environmentální senzitivitu chce rozvíjet.

Je zřejmé, že vymezení pojmu environmentální senzitivity přináší i po třiceti letech jisté nejednoznačnosti. Důležitou roli hrají i související metodologické diskuse. $V$ českém prostředí je zmiňuje například Kulhavý (2009), který interpretuje kritické názory Stephena Gougha (1999).

Anette Goughová (1999) zpochybňuje Tannerovo východisko v převzetí současných environmentálních aktivistů jako modelových vzorů pro děti. Podle ní je současná generace př́liš odlišná, a je proto problematické vycházet $\mathrm{z}$ toho, co $\mathrm{v}$ jiných podmínkách formulovalo generaci jejích rodičů. Na další metodologické problémy poukazují Payne (1999), S. Gough (1999) či samotná Chawlová (1998a). Je napríklad zjevné, že respondenti svoji osobní minulost konstruují na základě toho, jak se vnímají v současnosti. Skutečné faktory, které je $v$ jejich životní dráze ovlivnily, ale mohly být jiné.

Bustan a kol. (2003) ve svém výzkumu zjistili, že zkušenostem v přírodě připisují srovnatelně velký význam respondenti s vysokým, ale i s nízkým stupněm environmentální senzitivity. Zaměření výzkumů významných životních zkušeností na respondenty vykazující vysoký stupeň environmentálně odpovědného chování proto může vést $k$ nesprávné interpretaci významu př́rodních prožitků.

Podle Bögeholzové (2006) nezáleží pouze na četnosti pobytu $\vee$ př́rodě, ale i na interpretaci prožitku. Utilitární vnímání pobytu $v$ př́rodě nemá stejný efekt, jako např́klad vnímání estetické či ekologické.

Podle Vadaly a kol. (2007) mají některé typy přírodních zkušeností větší formativní vliv, než jiné ("hry s přírodou" větší, než "hry v prrírodě"). Programy environmentální výchovy by proto měly kromě pouhého zprostředkování kontaktu účastníka s prírodou obsahovat takové aktivity, které prožívanou zkušenost posílí, dají ji pozitivní náboj a umožní ji účastníkům vhodně interpretovat. Metzger a McEwan (1999) při evaluaci vlivu outdoorového programu zjistili, že nejenom kontakt $\mathrm{s}$ př́rodou, ale i aktivity programu jsou pro rozvíjení environmentální senzitivity důležité. Podle Swarda (1999) by outdoorové programy pro děti měly zahrnovat aktivity na objevování př́rody, péči o rostliny či zviŕata, důležitou roli hraje také lektor a rodiče jako modelové vzory. 
Pro autory zabývající se metodikou environmentální výchovy je typické, že spíše než o rozvíjení environmentální senzitivity, mluví o vlivu svých programů na rozvíjení vztahu k prírodě, postojům $\mathrm{k}$ životnímu prostředí, vnímání přírody či radosti $z$ přírody. V sedmdesátých letech 20. století vznikly a rozšírily se dva významné proudy environmentální výchovy, které na rozvíjení těchto oblastí kladly dưraz.

Prvním byla výchova o Zemi, která rozvinula koncept vysoce propracovaných programů rozvíjejících současně kognitivní i afektivní doménu (Matre, 1999). Aktivity, zaměřené na rozvíjení vztahu k přírodě, jsou integrovanou součástí komplexních programù a mají podrobně rozpracovanou metodiku. Matre (1999) rozlišuje několik typů aktivit, které se zaměřují na "ostření smyslư", tedy rozvíjení vnímavosti vưči přírodě, ponoření do prírody prostřednictvím prožitku samoty či interpretativní výlety integrující a reflektující získané znalosti s rozvinutou schopností přírodu vnímat a prožívat. Podle realizovaných výzkumů tento přístup pozitivně ovlivňuje postoje žáků k přírodě a životnímu prostředí (Martin, 2003; Johnson a Manoli, 2008).

Souběžně s výchovou o Zemi se rozvíjí metodika tzv. modelu učení plynutím (flow learning model) Josepha Cornella. Cornell (1987, 1989, 1998) vycházel především z prostředí neformální výchovy. V rámci své zkušenosti lektora "přírodních procházek" (nature walks) připravil jednak řadu aktivit zaměřených na "sdílení radosti z přírody", jednak jednoduchou metodiku pro jejich seřazení do funkčního celku (flow learning model). Podle něj je zpravidla vhodné rozdělit program v př́rodě do čtyř fází. Ve fázi Zaujetí (awaken enthusiasm) je úkolem lektora děti „naladit” na program v prírodě. Zařazují se proto zábavné aktivity, které mají děti nadchnout a získat pro další práci. Ve fázi Ostření pozornosti (focus attention) se děti pomocí jednoduchých aktivit učí vnímat jednotlivosti přírody, zpravidla s vyřazením některého ze smyslù (např. zavázání očí) či posílením jiného (např. soustředěním se na zvuky). Fáze Přímé zkušenosti (direct experience) obsahuje aktivity zprostředkovávající nejhlubší prožitek přírody v rámci programu. Konečně ve fázi Sdílení inspirace (sharing inspiration) mưže lektor zařadit inspirující příběhy modelující lásku k př́rodě a umožnit skupině reflektovat své zážitky.

Zatímco dílčí aktivity J. Cornella jsou v České republice poměrně známy (Witt, 2008), model učení plynutím byl až donedávna opomíjen v metodické i výzkumně orientované literatuře. Činčera a Komárková (2010) zkoumali efekt programu využívajícího aktivity z Cornellových publikací, bez přímého využití modelu učení plynutím. Evaluace prokázala, že na konci programu došlo ve srovnání se stavem před jeho zahájením $\mathrm{k}$ proměně $\mathrm{v}$ postavení přírody a přírodních prvků ve výtvarné reflexi posledního pobytu přírodě dětmi. Efekt programu využívajícího model učení plynutím na rozvíjení environmentální senzitivity či souvisejících proměnných nebyl u nás dosud zkoumán.

\section{Program Les je přítel člověka Sdružení TEREZA}

Program "Les je př́tel člověka" je 180 minut dlouhý program určený pro žáky základní školy. Cílem je rozvoj environmentální senzitivity žákư. Žáci se při pobytu v lese mají učit zaměřovat se na jeho vnímání více smysly, vžít se do konkrétního živočicha či rostliny, zkusit vnímat svět jeho očima a reflektovat to a vyjádřit, jak na ně les působil (interní materiál Sdružení TEREZA). Program existuje ve variantě pro první a pro druhý stupeň, které se od sebe mírně liší ve volbě aktivit.

Program se skládá ze 7-8 aktivit, provázaných podle zásad modelu učení plynutím Cornell (1989, 1998). Ve fázi Zaujetí žáci prvního stupně hrají jednoduchou soutěživou hru, ve které si opakují znalosti o př́rodě a zkouší svoji pozornost. Ve fázi Ostření pozornosti kreslí zvuky okolní přírody, soustředí se na barvy a na přírodní mikrodetaily. Fáze Prímé zkušenosti obsahuje aktivitu na hledání "svého" stromu pomocí hmatu a imaginativní aktivitu, ve které si žáci dramatickou formou zkoušejí představit růst lesa. 
Ve fázi Sdílení inspirace kreslí a prezentují „svůj les" a následně reflektují svoje zážitky z programu.

Verze programu pro žáky druhého stupně se lišila především $v$ úvodní aktivitě na Zaujetí, kdy byla zařazena kooperativní aktivita, ve které žáci z vlastních těl sestavovali strom. Druhá odlišnost pak přišla ve fázi Přímé zkušenosti, kdy byla navíc zařazena aktivita, ve které si žáci vzájemně zprostředkovávají zrakový prožitek př́rody.

Všechny aktivity byly vybrány z publikací Josepha Cornella $(1989,1998)$ a jejich zařazení odpovídalo uvedeným doporučením jak pro věkovou vhodnost, tak pro jejich zakomponování do modelu učení plynutím.

Program byl realizován od konce března do konce června 2012 v přírodních parcích na území hlavního města Prahy (Prokopské údolí, Divoká Šárka, Okrouhlík, Stromovka, Kunratický les, Radotínské údolí). Zúčastnilo se jej celkem 15 tř́d. škol.

Pro potřebu evaluace byla získána data od celkem 8 tříd ze sedmi různých pražských

Tab. č. 1 Složení vzorku respondentů

\begin{tabular}{|l|l|l|l|l|l|l|l|l|l|}
\hline $\begin{array}{l}\text { Žáků } \\
\text { celkem }\end{array}$ & Věk & SD & Chlapců & Dívek & $\begin{array}{l}\text { První stupeň } \\
(\mathrm{N}=49)\end{array}$ & Druhý stupeň $(\mathrm{N}=50)$ \\
\hline 99 & 10,5 & 2,35 & 55 & 43 & $\begin{array}{l}\text { Druhý } \\
\text { ročník }\end{array}$ & $\begin{array}{l}\text { Čtvrtý } \\
\text { ročník }\end{array}$ & $\begin{array}{l}\text { Šestý } \\
\text { ročník }\end{array}$ & $\begin{array}{l}\text { Sedmý } \\
\text { ročník }\end{array}$ \\
\hline
\end{tabular}

Z celkových 99 respondentů se jich 49 zúčastnilo varianty programu pro první stupeň a 50 varianty pro druhý stupeň. $\vee$ rámci každého stupně byly zastoupeny $d v a$ ročníky. Jeden z respondentů neuvedl své pohlaví.

\section{Metodika evaluace}

Provedená evaluace měla odpovědět na otázku, jaký vliv má program na smyslové zážitky, které si děti vybavují z návštěvy lesa. Pro její zodpovězení byl využit jednoduchý design typu pretest/posttest. Respondenti vyplnili pretest těsně před zahájením programu. Posttest pak vyplnili ve škole v odstupu 1-3 týdnů od ukončení programu.

$\checkmark$ rámci dotazníku měli žáci zavzpomínat, jaké to bylo, když byli naposledy $v$ lese. "Stojíš tam, kolem sebe máš stromy..."

Jaké barvy kolem sebe vidišs (napiš nám taky, na čem je vidíš - napřiklad "červený list s hnědými tečkami")

Jaké zvuky kolem sebe slyšiš (napiš nám zase, kdo je asi vydává, a popiš, jak se liší - napríklad „pták někde za mnou dělá píp-kuňk")

Na co sis v lese šáhl/-a a jaké to bylo (např. "na pařez, byl suchý a tvrdý")

Pod každou otázkou měli žáci 5-6 odrážek, které je měly motivovat k uvádění většího počtu různých podnětů. 

tabulky:

Odpovědi byly přepsány a následně kvantifikovány pomocí následující kódovací

Tab. č. 2 Kódování smyslových vjemů

\begin{tabular}{|c|c|c|c|c|}
\hline $\begin{array}{l}\text { Smyslový } \\
\text { vjem }\end{array}$ & Kritérium hodnocení & Modelové situace & Př́klad & Hodnocení \\
\hline \multirow[t]{5}{*}{ Zrak } & $\begin{array}{l}\text { Každé nové přiřazení } \\
\text { barvy na předmět v } \\
\text { lese, který je součástí } \\
\text { lesního ekosystému }\end{array}$ & $\begin{array}{l}\text { Uvedena barva spojená s } \\
\text { předmětem, uvedené spojení } \\
\text { ještě nebylo uvedeno, předmět } \\
\text { je součástí lesního ekosystému }\end{array}$ & $\begin{array}{l}\text { Zelené } \\
\text { listí }\end{array}$ & 1 \\
\hline & & $\begin{array}{l}\text { Uvedena barva spojená se } \\
\text { dvěma či více přírodními } \\
\text { předměty }\end{array}$ & $\begin{array}{l}\text { Zelené } \\
\text { listí a } \\
\text { jehličí }\end{array}$ & 2 \\
\hline & & Uvedena jen barva & Zelená & 0 \\
\hline & & Uveden jen předmět & Jehličí & 0 \\
\hline & & $\begin{array}{l}\text { Uveden předmět lidského } \\
\text { původu }\end{array}$ & $\begin{array}{l}\text { Červená } \\
\text { čepice }\end{array}$ & 0 \\
\hline \multirow[t]{4}{*}{ Sluch } & $\begin{array}{l}\text { Uvedení různých } \\
\text { zvukových vjemů } \\
\text { předmětů, které jsou } \\
\text { součástí lesního } \\
\text { ekosystému }\end{array}$ & $\begin{array}{l}\text { Uveden zvuk a jeho původce, } \\
\text { který je součástí lesního } \\
\text { ekosystému }\end{array}$ & $\begin{array}{l}\text { Píp } \\
\text { ptáčka }\end{array}$ & 1 \\
\hline & & $\begin{array}{l}\text { Uveden přírodní původce zvuku } \\
\text { bez charakteristiky zvuku či s } \\
\text { obecnou charakteristikou }\end{array}$ & $\begin{array}{l}\text { Zpívání } \\
\text { ptáčka } \\
\text { Veverka }\end{array}$ & 1 \\
\hline & & Uveden zvuk bez původce & Píp & 0 \\
\hline & & $\begin{array}{l}\text { Uveden zvuk s původcem, který } \\
\text { není součástí lesního } \\
\text { ekosystému, je lidského původu }\end{array}$ & Mobil & 0 \\
\hline \multirow[t]{3}{*}{ Hmat } & $\begin{array}{l}\text { Uvedení různých } \\
\text { hmatových vjemů } \\
\text { předmětů, které jsou } \\
\text { součástí lesního } \\
\text { ekosystému }\end{array}$ & $\begin{array}{l}\text { Uveden hmatový vjem a jeho } \\
\text { původce, který je soućástí } \\
\text { lesního ekosystému }\end{array}$ & $\begin{array}{l}\text { Houba } \\
\text { byla } \\
\text { mokrá }\end{array}$ & 1 \\
\hline & & $\begin{array}{l}\text { Uveden zdroj hmatového } \\
\text { podnětu, který je součástí } \\
\text { lesního ekosystému }\end{array}$ & Houba & 1 \\
\hline & & $\begin{array}{l}\text { Uveden hmatový vjem s } \\
\text { původcem, který není součástí } \\
\text { lidského ekosystému }\end{array}$ & $\begin{array}{l}\text { Papír byl } \\
\text { studený }\end{array}$ & 0 \\
\hline
\end{tabular}


Zatímco pro bodování zrakových vjemů bylo vyžadováno spojení „barva-předmět", pro kódování sluchových a hmatových podnětů bylo bodováno i pouhé uvedení zdrojů smyslového vjemu. Při analýze dat bylo zjevné, že pro respondenty je snazší uvádět barvy, než popisovat zvukové či hmatové vjemy. Při aplikaci stejného pravidla jako pro zrakové vjemy by proto výsledek mohl být přiliš zkreslen vyjadřovacími schopnostmi žáků. Pro zajištění validity bylo kódování provedeno dvěma hodnotiteli.

Počty různých smyslových vjemů $v$ pretestu a posttestu byly následně porovnány a vyhodnoceny pomocí Wilcoxonova párového testu a znaménkového testu při alfa =0,05. Každý smyslový vjem byl vyhodnocován zvlášt́. Součástí hodnocení je jednoduchá kvalitativní analýza, která zde slouží spíše pro dokreslení kvantitativních dat.

\section{Výsledky}

$\checkmark$ první části byly vyhodnoceny souhrnné výsledky pro celou skupinu respondentů. Kalkulace byla provedena nejprve Wilxoconovým párovým testem $(\mathrm{p} / \mathrm{w})$ a následně znaménkovým testem $(\mathrm{p} / \mathrm{z})$.

Tab. č. 3 Porovnání počtu udaných smyslových vjemů před a po programu

\begin{tabular}{|l|l|l|l|l|l|l|}
\hline Smyslový vjem & Počet respondentů & Průměr před & Průměr po & $Z$ & $P / w$ & $P / z$ \\
\hline Zrak & & 3,23 & 3,95 & 2,51 & $0,01^{*}$ & $0,01^{*}$ \\
\hline Sluch & 99 & 1,77 & 2,19 & 2,38 & $0,01^{*}$ & $0,04^{*}$ \\
\hline Hmat & & 2,75 & 3,02 & 0,93 & 0,32 & 0,72 \\
\hline
\end{tabular}

Poznámka: Hodnota „z" se vztahuje k Wilcoxonovu testu. "*” udává statisticky významné rozdíly.

Je zřejmé, že s výjimkou počtu uvedených hmatových vjemů se počty ostatních smyslových vjemů zvýšily.

Porovnání celé skupiny podle pohlaví ukázalo důležité rozdíly. Zatímco u chlapců statisticky významné rozdíly před a po programu nebyly naměřeny, u dívek se objevil statisticky významný rozdíl pro počty zrakových $(z=2,05, p=0,03)$ i sluchových vjemů $(z=3,5, p<0.000)$. Rozdíly $v$ počtech uváděných smyslových vjemů mezi chlapci a dívkami byly statisticky významné ve všech případech, kromě počtu zvuků uvedených před programem (analýza byla provedena Mann-Whitneyho U testem). Dívky uváděly ve všech prípadech více smyslových podnětů, než chlapci.

Tab. č. 4 Porovnání počtu udaných smyslových vjemů mezi chlapci a dívkami

\begin{tabular}{|l|l|l|l|l|l|l|l|}
\hline & Počet & Barvy před & Barvy po & Zvuky před & Zvuky po & Hmat před & Hmat po \\
\hline Dívky & 55 & 3,76 & 4,6 & 1,96 & 2,75 & 3,32 & 3,7 \\
\hline Chlapci & 43 & 2,46 & 3,23 & 1,53 & 1,53 & 2,09 & 2,2 \\
\hline
\end{tabular}

Korelační analýza mezi věkem a počty uváděných smyslových vjemů přinesla dvě zjištění. Věk respondentů pozitivně koreluje $s$ počtem uváděných vjemů na všech třech 
kategoriích před programem. Korelaci je možné hodnotit jako středně silnou. Korelace mezi věkem a počtem podnětů po programu nebyly statisticky významné. Starší respondenti tedy uváděli před programem více podnětů než mladší.

Počty uváděných vjemů spolu ve všech kategoriích pozitivně korelují, korelace je možné označit jako středně silné či silné. Pokud tedy respondenti uváděli více vjemů u jednoho smyslu, uváděli jich více i u ostatních dvou.

Tab. č. 5 Korelace mezi věkem a počtem udávaných smyslových vjemů v jednotlivých kategoriích

\begin{tabular}{|l|l|l|l|l|l|l|l|l|}
\hline & Věk & Barvy před & $\begin{array}{l}\text { Barvy } \\
\text { po }\end{array}$ & Zvuky před & Zvuky po & $\begin{array}{l}\text { Hmaty } \\
\text { před }\end{array}$ & Hmaty po \\
\hline Věk & 1 & $0,29^{*}$ & $-0,02$ & $0,38^{*}$ & $-0,04$ & $0,35^{*}$ & 0,15 \\
\hline Barvy před & $0,29^{*}$ & 1 & $0,46^{*}$ & $0,48^{*}$ & $0,36^{*}$ & $0,45^{*}$ & $0,47^{*}$ \\
\hline Barvy po & $-0,02$ & $0,46^{*}$ & 1 & $0,41^{*}$ & $0,52^{*}$ & $0,37^{*}$ & $0,66^{*}$ \\
\hline Zvuky pred & $0,38^{*}$ & $0,48^{*}$ & $0,41^{*}$ & 1 & $0,49 *$ & $0,46^{*}$ & $0,39^{*}$ \\
\hline Zvuky po & $-0,04$ & $0,36^{*}$ & $0,52^{*}$ & $0,49^{*}$ & 1 & $0,29 *$ & $0,62^{*}$ \\
\hline Hmaty před & $0,35^{*}$ & $0,45^{*}$ & $0,37^{*}$ & $0,46^{*}$ & $0,29 *$ & 1 & $0,45^{*}$ \\
\hline Hmaty po & 0,15 & $0,47^{*}$ & $0,66^{*}$ & $0,39^{*}$ & $0,62^{*}$ & $0,45^{*}$ & 1 \\
\hline
\end{tabular}

Velikost rozdílu mezi počtem vjemů $v$ pretestu a $v$ posttestu se lišila mezi jednotlivými ročníky. Pro další analýzu byli respondenti rozdělení na skupinu První stupeň (druhý a čtvrtý ročník), N=49 a Druhý stupeň (šestý a sedmý ročník), N=50. Dílčí analýzy byly dále prováděny i pro každý ročník zvláštt.

U žáků ze skupiny První stupeň byl statisticky významný rozdíl naměřen u všech tři proměnných (zrak, sluch, hmat). Naopak ve skupině Druhý stupeň nebyl takový rozdíl zjištěn ani $v$ jednom prípadě. Všechny výpočty byly provedeny pomocí Wilcoxonova párového testu.

Tab. č. 6 Porovnání počtu udaných smyslových vjemů před a po programu pro skupinu První stupeň

\begin{tabular}{|l|l|l|l|l|l|}
\hline Smyslový vjem & Počet respondentů & Průměr před & Průměr po & $Z$ & $P$ \\
\hline Zrak & & 2,24 & 3,89 & 3,89 & $<0.000^{*}$ \\
\hline Sluch & & & & & \\
\hline Hmat & & 1,18 & 2,2 & 3.79 & $<0.000^{*}$ \\
\hline
\end{tabular}


Značný nárůst je patrný zejména u rozdílu $\mathrm{v}$ počtu zrakových vjemů, kdy $v$ pretestu byla nejčastější hodnota (modus) nula, zatímco $v$ posttestu byl modus šest.

Tab. č. 7 Porovnání počtu udaných smyslových vjemů před a po programu pro skupinu Druhý stupeň

\begin{tabular}{|c|c|l|l|l|l|l|}
\hline Smyslový vjem & Počet respondentů & Průměr před & Průměr po & $Z$ & P \\
\hline Zrak & & 4,2 & 4,02 & 0,32 & 0,74 \\
\hline Sluch & 50 & 2,36 & 2,18 & 1,33 & 0,18 \\
\hline Hmat & & 3,66 & 3,48 & 1,2 & 0,22 \\
\hline
\end{tabular}

Analýza provedená po jednotlivých ročnících je nutně kvůli malé velikosti skupin zjednodušující. Statisticky významné rozdíly $v$ počtu zrakových $(z=3,68, p<0.000)$, sluchových $(\mathrm{z}=4,7, \mathrm{p}<0.000)$ a hmatových $(\mathrm{z}=1,89, \mathrm{p}=0,05)$ vjemù byly zaznamenány pouze u žáků druhého ročníku $(N=36)$. U žáků čtvrtého $(N=13)$, šestého $(N=20)$ ani sedmého $(\mathrm{N}=30)$ ročníku nebyl takový efekt zaznamenán.

Rozdíly $v$ kvalitě reflektovaných vjemů spočivaly především ve vyšší konkrétnosti reflexe. Zejména respondenti $z$ obou druhých ročníků $v$ pretestu zpravidla uváděli pouze barvy, zatímco $v$ posttestu barvy propojovali $\mathrm{s}$ konkrétními prírodními objekty. Méně výrazně byla vyšší míra konkretizace zřejmá i z reflexí ostatních dvou smyslů:

Tab. č. 8 Kvalitativní porovnání vybraných reflexí

\begin{tabular}{|c|c|c|c|}
\hline Respondent & Před & Po & Poznámka \\
\hline $\begin{array}{l}\text { Dívka, } 7 \text { let, } \\
\text { 2. roč. }\end{array}$ & $\begin{array}{l}\text { hnědá, zelená, } \\
\text { žlutá, modrá, } \\
\text { bílá, okrová } \\
\text { ( } 0 \text { bodů) }\end{array}$ & $\begin{array}{l}\text { žlutou na listu, zelenou trávu, } \\
\text { oranžový kmen, hnědý kmen } \\
\text { ( } 4 \text { body) }\end{array}$ & $\begin{array}{l}\text { Respondentka propojila } \\
\text { barvy s př́rodními objekty, } \\
\text { rozlišila dvě barevné } \\
\text { varianty kmene. }\end{array}$ \\
\hline $\begin{array}{l}\text { Dívka, } 8 \text { let, } \\
\text { 2. roč. }\end{array}$ & $\begin{array}{l}\text { zelený list, } \\
\text { hnědý strom, } \\
\text { hnědošedé } \\
\text { dřevo, hnědé } \\
\text { šišky } \\
\text { ( } 4 \text { body) }\end{array}$ & $\begin{array}{l}\text { hnědý žalud, hnědé dřevo, } \\
\text { zelený stonek, zelenou trávu, } \\
\text { zelený list, červenou kytku, } \\
\text { šedá hora, červený motýl, } \\
\text { žlutočerný hmyz, zelený list, } \\
\text { žlutá kytka, hnědá větev, } \\
\text { zelený stonek } \\
\text { (11 bodů) }\end{array}$ & $\begin{array}{l}\text { Reflexe zřejmě značně } \\
\text { senzitivní respondentky } \\
\text { ukazuje v posttestu řadu } \\
\text { méně výrazných přírodních } \\
\text { objektů (stonek, žalud, } \\
\text { hmyz). }\end{array}$ \\
\hline $\begin{array}{l}\text { Dívky, } 8 \text { let, } \\
\text { 2. roč. }\end{array}$ & $\begin{array}{l}\text { píp, bum, psss, } \\
\text { hươư } \\
\text { ( } 0 \text { bodů) }\end{array}$ & $\begin{array}{l}\text { velký pták zprava pěkně } \\
\text { zpíval, malý ptáček zleva } \\
\text { nádherně cvrliká, stromy ze } \\
\text { všech stran šumí, za mnou } \\
\text { padá větev a přímo přede } \\
\text { mnou spadla šiška } \\
\text { ( } 5 \text { bodů) }\end{array}$ & $\begin{array}{l}\text { Respondentka v posttestu } \\
\text { prokazuje bohatší } \\
\text { a adresnější reflexe, přímo } \\
\text { spojené s jejím prožitkem. }\end{array}$ \\
\hline $\begin{array}{l}\text { Chlapec, } 7 \\
\text { let, 2. roč. }\end{array}$ & $\begin{array}{l}\text { Na list byl } \\
\text { měkký a zelený } \\
\text { ( } 2 \text { body) }\end{array}$ & $\begin{array}{l}\text { Na list byl měkký a mokrý. Na } \\
\text { kmen byl lepkavý. Na kámen } \\
\text { byl tvrdý. Na větev byla } \\
\text { drhlavá. } \\
\text { ( } 4 \text { body) }\end{array}$ & $\begin{array}{l}\text { Respondent rozvíjí téma z } \\
\text { pretestu, ale obohacuje je } \\
\text { o další reflexe. }\end{array}$ \\
\hline
\end{tabular}




\section{Diskuse}

Výsledky je třeba interpretovat s vědomím existujících limitů. Počet respondentů byl poměrně malý, zejména při dělení do menších skupin podle pohlaví, stupňu či ročníků. Z patnácti tř́́d se podařilo získat data pouze od osmi. $V$ důsledku jsou výsledky nutně spíše orientační sondou a na jejich základě Ize formulovat spíše podněty pro další zkoumání než finální stanoviska.

Nabízí se otázka, zda schopnost reflektovat a zaznamenat smyslové vjemy skutečně souvisí s konceptem environmentální senzitivity. Vztah mezi vnímavostí a senzitivitou odkazuje na Krajhanzla (2010), v širším pojetí ale i na Bögeholzovou (2006). Jestliže přijmeme předpoklad, že nezáleží pouze na četnosti pobytu $v$ prírodě, ale i na interpretaci takového prožitku, můžeme také předpokládat, že schopnost reflektovat větší množství prírodních smyslových podnětů může vést $\mathrm{k}$ utváření neutilitárního modu pobytu $\mathrm{v}$ př́rodě, a posílit tak zájem o prírodu a odpovědné environmentální chování. Další výzkumy by proto mohly kombinovat použitou metodiku s dalším nástrojem zaměřeným například na zájem o estetické či badatelské aktivity žáků v prrírodě.

Přestože výsledky naznačují efekt programu na žáky prvního stupně, můžeme dále zvažovat, zda príčinou bylo absolvování programu vedeného podle modelu učení plynutím, či zda by podobný efekt znamenalo pouhé vystavení dětí nestrukturovaným aktivitám $\checkmark$ lese. Taková otázka je pro diskusi o směřování environmentální výchovy dost důležitá. Znamená Cornellova metodika prínos oproti např́klad pouhým turistickým aktivitám, výletům do př́rody atd.? Podle Metzgera a McEwana (1999) mají řízené aktivity svưj význam, je ale zjevné, že efekt každé metodiky může být specifický a to i pro každý typ cílové skupiny. Přestože se zdá pravděpodobné, že aktivity, ve kterých se žáci cíleně učili vnímat pŕírodu zrakem, sluchem a hmatem a svoji zkušenost pak reflektovali, odráží svůj efekt ve zvýšeném počtu zaznamenaných vjemů, bylo by užitečné tuto domněnku ověřit dalším experimentem.

Pokud přijmeme tezi o efektu programu, je zjevné, že funguje různě pro jednotlivé skupiny žáků. Zdá se, že dívky jsou vưči přírodě vnímavější než chlapci a program na ně také funguje lépe než na chlapce. Genderové rozdíly ve vnímání a postojích vưči přírodě byly zjištěny i v jiných výzkumech. Ženy se např́ílad v lese více bojí (Berg a Heijne, 2005; Skår, 2010). Múže taková obava souviset s jejich větší vnímavostí? Existuje souvislost mezi obavami a environmentální senzitivitou?

Pozitivní korelace mezi věkem a počtem uváděných vjemů není překvapující a pravděpodobně souvisí nejenom s větší zkušeností, ale i s rozvinutějšími vyjadřovacími schopnostmi. Starší děti jsou schopny vyjádřit více smyslových podnětů již před programem, současně na ně program v této oblasti nepůsobil. Naopak pro mladší děti (zejména z 2. tř́́dy) byla reflexe smyslových vjemů přírody před programem obtížnější. Po programu pak byly schopny uvést výrazně vyšší počet vjemů a častěji také dokázaly vjemy konkretizovat a propojit s př́rodním objektem. Je proto možné předpokládat, že program lépe naplňuje své cíle při práci s mladšími dětmi na prvním stupni, kde může přispívat ke zvýšení jejich vnímavosti k prírodě.

Pro děti na druhém stupni se takový efekt nezdá pravděpodobný. Přestože žáci prochází trochu odlišnou variantou programu, rozdíly ve skladbě aktivit jsou jen malé a nezdá se, že by tato varianta programu byla metodicky hưře připravená. Ve fázi Zaujetí (aktivita Postav strom) se žáci ve srovnání s prvostupňovou variantou možná spíše než na vnímání okolního prostředí obracejí k určité animaci prírody (Chawlová, 1998b), vnímání přírody je na druhé straně posíleno aktivitou Fotoaparát zařazenou do fáze Přímé zkušenosti.

Pravděpodobnější vysvětlení rozdílného fungování programu je tedy věk dětí. Zatímco pro malé děti je príroda atraktivní, na druhém stupni se zájem žáků o prírodu odklání směrem k intra- a inter-sociálním tématům (Krajhanzl, 2012). Z provedené 
evaluace nelze vyvodit, zda program nemůže mít pro žáky na druhém stupni nějaký jiný přínos. Zdá se ale, že vnímavost $\mathrm{k}$ přírodě není pro děti $v$ tomto věku téma, kterým by se měly potřebu zabývat. Vzhledem k malému počtu respondentů je ale tento závěr nutně pouze orientační.

Ve vztahu k realizátorovi programu z evaluace nevyplývají podněty pro změnu metodiky programu. Program by ale měl být přednostně nabízen žákům na prvním stupni. Pro rozvíjení environmentální senzitivity na druhém stupni by možná byly vhodnější jinak zaměřené programy, možná právě takové, které spíše než individuální vnímání posilují spolupráci a "projekci" do př́rody. Takové programy by pak měly být evaluovány jinou metodikou.

Přestože je použitá evaluační metodika poměrně jednoduchá, zdá se, že je pro žáky na prvním stupni dobře použitelná. Jednoduchá kódovací tabulka umožňuje aplikaci daného nástroje i $v$ běžném provozu středisek ekologické výchovy. Důsledný sběr dat by tak mohl přinést cenná zjištění o efektivitě i limitech metodiky modelu učení plynutím.

\section{Literatura}

- van den Berg, A. E., \& ter, M., Heijne (2005). Fear versus Fascination: An exploration of emotional responses to natural threats. Journal of Environmental Psychology, 25(3), 261272. Retrieved from http://linkinghub.elsevier.com/retrieve/pii/S0272494405000551 http://dx.doi.org/10.1016/j.jenvp.2005.08.004

- Bögeholz, S. (2006). Nature experience and its importance for environmental knowledge, values and action: recent German empirical contributions.Environmental Education Research, 12(1), 65-84. Retrieved from http://www.tandfonline.com/doi/abs/10.1080/13504620500526529 http://dx.doi.org/10.1080/13504620500526529

- Chawla, L. (1999). Life Paths Into Effective Environmental Education. The Journal of Environmental Education, 31(1), 15-26. Retrieved from http://www.tandfonline.com/doi/abs/10.1080/00958969909598628 http://dx.doi.org/10.1080/00958969909598628

- Chawla, L. (1998). Research Methods to Investigate Significant Life Experiences: review and recommendation. Environmental Education Research, 4(4), 383-397. Retrieved from http://www.tandfonline.com/doi/abs/10.1080/1350462980040403 http://dx.doi.org/10.1080/1350462980040403

- Chawla, L. (1998). Significant Life Experiences Revisited: A Review of Research on Sources of Environmental Sensitivity. The Journal of Environmental Education, 29(3), 11-21. Retrieved from $\quad$ http://www.tandfonline.com/doi/abs/10.1080/00958969809599114 http://dx.doi.org/10.1080/00958969809599114

- Činčera. J, , \& Komárková, M. (2010). Využití kresby pro evaluaci programu na rozvíjení environmentální senzitivity mladších dětí. Envigogika, 5(2),

- Cornell, J. (1987). Listening to the Nature. How to Deepen Your Awareness of Nature. Nevada City: DAWN Publications.

- Cornell, J. (1989). Sharing the Joy of Nature. Nature activities for All Ages. Nevada City: DAWN Publications.

- Joseph, C. (1998). Sharing Nature with Children. Nevada City: DAWN Publications.

- Furihata, S., Ishizaka, T., Hatakeyama, M., Hitsumoto, M., \& Ito, S. (2007). Potentials and Challenges of Research on "Significant Life Experiences" in Japan.Children, Youth and Environments, 17(4), 207-228.

- Gough, A. (1999). Kids Don't Like Wearing the Same Jeans as their Mums and Dads: so whose 'life' should be in significant life experiences research.Environmental Education 
Research, 5(4),

383-394.

Retrieved

from

http://www.tandfonline.com/doi/abs/10.1080/1350462990050404

http://dx.doi.org/10.1080/1350462990050404

- Gough, S. (1999). Significant Life Experiences (SLE) Research: a view from somewhere. Environmental Education Research, 1999, vol. 5, n. 4, p. 353-363.Environmental Education Research, 5(4), 353-363. Retrieved from http://www.tandfonline.com/doi/abs/10.1080/1350462990050402 http://dx.doi.org/10.1080/1350462990050402

- Hungerford, H. R., \& Volk, T. L. (1990). Changing Learner Behavior Through Environmental Education. The Journal of Environmental Education, 21(3), 8-21. Retrieved from http://www.tandfonline.com/doi/abs/10.1080/00958964.1990.10753743 http://dx.doi.org/10.1080/00958964.1990.10753743

- Hungerford, H., Peyton, B. R., \& Wilke, R. J. (1980). Goals for Curriculum Development in Environmental Education. The Journal of Environmental Education,1980(11), 42-47. Retrieved from http://www.tandfonline.com/doi/abs/10.1080/00958964.1980.9941381 http://dx.doi.org/10.1080/00958964.1980.9941381

- Jančaříková, K. (2009) Výsledky empirického výzkumu dětských kontaktů s prírodou. In Člověk + príroda=udržitelnost. Texty o proměnè vztahu lidí $k$ prírodè, environmentální výchově a udržitelnosti (pp. 16-27). Praha: Zelený kruh.

- Johnson, B., \& Manoli, C. C. (2008). Using Bogner and Wiseman's Model of Ecological Values to measure impal on an earth education programme on children's environmental perceptions. Environmental Education Research, 2008, vol. 14, no. 2, p. 115-127. Environmental Education Research, 2008(14), 115-127. Retrieved http://www.tandfonline.com/doi/abs/10.1080/13504620801951673 http://dx.doi.org/10.1080/13504620801951673

- Kim, K. (2003). An Inventory for Assessing Environmental Education Curricula. The Journal of Environmental Education, 34(2), 12-18. Retrieved from http://www.tandfonline.com/doi/abs/10.1080/00958960309603495 http://dx.doi.org/10.1080/00958960309603495

- Krajhanzl, J. (2010). Charakteristika osobního vztahu k prírodě. Úvod do teorie a pojmosloví. [Disertační práce]. Praha: Univerzita Karlova.

- Krajhanzl, J. (2012) Špetka ekopsychologie pro ekopedagogickou praxi. In A. Máchal, H. Nováčková, \& L. Sobotková (Eds.), Uvod do environmentální výchovy a globálního rozvojového vzdělávání. Soubor učebních textů. Brno: Lipka.

- Kulhavý, V. (2009) Zkušenosti významné pro formování vztahu člověka k prírodě. In KRAJHANZL, J. a kol (Ed.), Člověk + príroda = udržitelnost? : Texty o proměně vztahů lidí $k$ prírodě, environmentální výchově a udržitelnosti. Praha: Zelený kruh. Retrieved from http://www.zelenykruh.cz/dokumenty/300409-clovekpriroda-fin.pdf

- Martin, D. (2003). Research in Earth Education. Zeitschrift für Erlebnispädagogik. Research in Earth Education. Zeitschrift für Erlebnispädagogik, 23(5), 32-47.

- MATRE, S. van, (1999) Earth Education .. a new beginning. In . Greenville: The Institute for Earth Education.

- Metzger, T., \& McEWEN, D. (1999). Measurement of Environmental Sensitivity. The Journal of Environmental Education, 30(4), 38-39. Retrieved from http://www.tandfonline.com/doi/abs/10.1080/00958969909601883 http://dx.doi.org/10.1080/00958969909601883

- Palmer, J. A., Suggate, J., Bajd, B., K.P., Paul Hart, , Ho, R. K. P., Ofwono-Orecho, J. K. W., ... Staden, C. V. (1998). An Overview of Significant Influences and Formative Experiences on the Development of Adults' Environmental Awareness in Nine Countries. Environmental Education Research, 4(4), 445-464. Retrieved from 
http://www.tandfonline.com/doi/abs/10.1080/1350462980040408 http://dx.doi.org/10.1080/1350462980040408

- Palmer, J. A., Suggate, J., Robottom, I. A. N., \& Hart, P. A. U. L. (1999). Significant Life Experiences and Formative Influences on the Development of Adults' Environmental Awareness in the UK, Australia and Canada. Environmental Education Research, 5(2), 181 200. Retrieved from http://www.tandfonline.com/doi/abs/10.1080/1350462990050205 http://dx.doi.org/10.1080/1350462990050205

- Pastorová, M. a kol., (2011). Doporučené očekávané výstupy. Metodická podpora pro výuku prưrezových témat na základních školách. Praha: Výzkumný ústav pedagogický. Retrieved from http://www.vuppraha.cz/nova-publikace-divize-vup-\%E2\%80\%93-doporuceneocekavane-vystupy-pro-zakladni-skoly

- Payne, P. (1999). The Significance of Experience in SLE Research. Environmental Education Research, 5(4), 365-381. Retrieved from http://www.tandfonline.com/doi/abs/10.1080/1350462990050403 http://dx.doi.org/10.1080/1350462990050403

- N.peterson, (2005) Factors Influencing the Development of Environmental Sensitivity. In In Essential Readings in Environmental Education (pp. 295-300). In HUNGERFORD, Harold H.; BLUHM, William J.; VOLK, Trudi L.; RAMSEY, John M. Essential Readings in Environmental Education. Champaign: Stipes, p. 295-300.

- Skår, M. (2010). Forest dear and forest fear: Dwellers' relationships to their neighbourhood forest. Landscape and urban planning, 98, 110-116.

- Sivek, D. J. (2002). Environmental Sensitivity among Wisconsin High School Students. Environmental Education Research, 8(2), 155-170. Retrieved from http://www.tandfonline.com/doi/abs/10.1080/13504620220128220 http://dx.doi.org/10.1080/13504620220128220

- $\quad$ Sward, K. L. (1999). Significant Life Experiences Affecting the Environmental Sensitivity of El Salvadoran Environmental Professionals. Environmental Education Research, 5(2), 201-206. Retrieved from http://www.tandfonline.com/doi/abs/10.1080/1350462990050206 http://dx.doi.org/10.1080/1350462990050206

- Sward, L. L., \& Marcinkowski, T. (2005) Environmental Sensitivity: A Review of the Research, 1980-1998. In H. H. Hungerford, W. J. Bluhm, T. L. Volk, \& J. M. Ramsey (Eds.), Essential Readings in Environmental Education (pp. 301-312). Champaign: Stipes.

- Tanner, T. (1998). On the Origins of SLE Research, Questions Outstanding, and Other Research Tradition. Environmental Education Research, 4(4), 399-418.

- The Tbilisi Declaration. 1977., (2005) Intergovernmental Conference on Environmental Education. In H. H. Hungerford, W. J. Bluhm, T. L. Volk, \& J. M. Ramsey (Eds.), Essential Readings in Environmental Education (pp. 13-16). Champaign: Stipes.

- Vadala, C. E., Bixler, R. D., \& James, J. Joy, (2007). Childhood Play and Environmental Interests: Panacea or Snake Oil. The Journal of Environmental Education, 39(1), 3-18. Retrieved from http://www.tandfonline.com/doi/abs/10.3200/JOEE.39.1.3-18 http://dx.doi.org/10.3200/JOEE.39.1.3-18

- Witt, R. (2008). Vnímejme prírodu všemi smysly. Horní Maršov: SEVER.

PhDr. Jan Činčera, Ph.D.

Autor vyučuje environmentální výchovu a prožitkovou pedagogiku na Technické univerzitě v Liberci. Jako evaluátor programů dále spolupracuje se středisky ekologické výchovy a organizacemi zabývajícími se globálním rozvojovým vzděláváním. 
profesní zaměření: environmentální výchova, vzdělávání pro udržitelný rozvoj, výchova o Zemi, evaluace programů, pedagogika volného času, informační věda

Email: jan.cincera@tul.cz 
Časopis Envigogika vydává Centrum pro otázky životního prostředí UK. Vývoj časopisu je podpořen projektem OP VK Mezioborová sít udržitelného rozvoje.

Více najdete na internetových stránkách projektu http://mosur.czp.cuni.cz
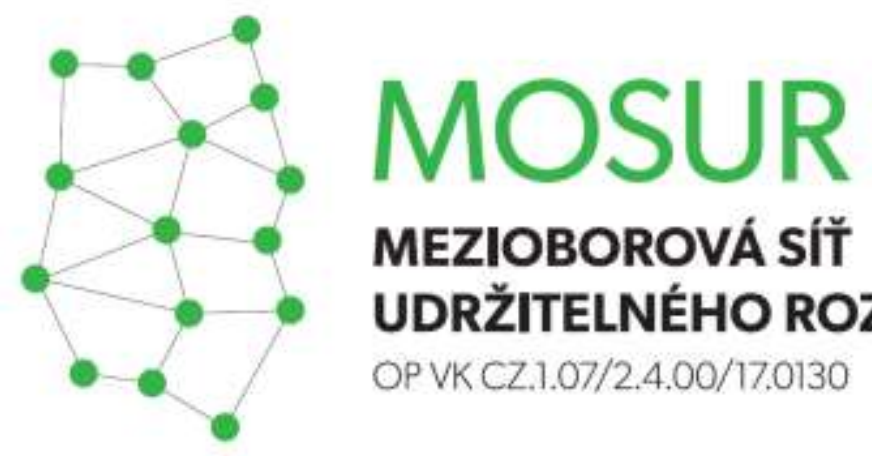

\section{MEZIOBOROVÁ SÍT̆} UDRŽITELNÉHO ROZVOJE

OPVKCZ.1.07/2.4.00/17.0130

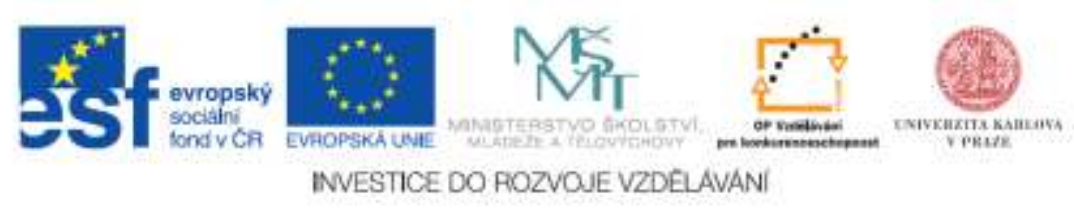

